J. Clin. Chem. Clin. Biochem.

Vol. 20, 1982, pp. 337-340

\title{
Studies on Antigens Useful for Detection of IgE Antibodies in (socyanate-Sensitized Workers ${ }^{1}$ )
}

\author{
By $M$. A. Dewair and $X$. Baur
}

Pulmonary Section (Prof. Dr. G. Fruhmann), Medical Clinic I (Prof. Dr. G. Riecker), Klinikum Großhadern,
University of Munich

(Received June 12, 1981/January 20, 1982)

Summary: Toluene diisocyanate was conjugated by two different methods to human serum albumin. These conjugates were used as antigens in the radio-allergo-sorbent-test (RAST) for detection of IgE antibodies-in sera of isocyanate-sensitized persons. Chemical analyses have shown that conjugates containing 18-28 mol of isocyanate residues per mol protein were much more potent antigens than those containing greater amounts of isocyanate residues. These results were confirmed by RAST inhibition experiments. The importance of optimization of the immunoradiometric methods for study of immunologic sensitization to isocyanates is discussed.

\section{Untersuchungen über Antigene, die sich zum Nachweis von IgE-Antikörpern bei Isocyanat-sensibilisierten Beschäftigten eignen}

Zusammenfassung: Toluol-diisocyanat wurde mittels zwei verschiedener Methoden an humanes Serumalbumin gekoppelt. Die Konjugate wurden im Radioallergosorbent-Test (RAST) als Antigen für den Nachweis von IgE-Antikörpern bei Isocyanatsensibilisierten Personen eingesetzt. Die chemischen Analysen ergaben, daß Konjugate mit 18-28 mol Isocyanat-Resten pro mol Protein wesentlich stärkere Antigene sind als Konjugate, die eine größere Anzahl von Isocyanat-Resten enthalten. Dieses Ergebnis konnte im RAST-Inhibitionstest bestätigt werden. Die Bedeutung einer Optimierung immunradiometrischer Methoden für den Nachweis immunologisch vermittelter Sensibilisierungen gegenüber Isocyanaten wird diskutiert.

\section{Introduction}

Isocyanates are one of the main causes of occupationally related obstructive lung diseases. It is estimated that 500000 persons are regularily exposed to isocyanate vapours in different industrial branches; approximately five percent of them develop respiratory hypersensitivity. Immunoglobulin $\mathrm{E}$ antibodies specific to isocyanate haptens have been found in the sera of some of these sensitized workers $(2,3,4)$. For the detection of these antibodies, synthetic antigens containing isocyanate haptens conjugated to carrier proteins have been used in radio=allergo:ṣoṛbent-tests (RAST) (1-4).

The reported percentages of persons immunologically sensitized to isocyanates differ from one research group to another. These variations may be due to differences in the chemical compositions of the synthetic antigens used in RAST. The aim of this study was to test the effect of the method of preparation of the antigens, their chemical composition and their capacities for detecting the specific antibodies.

1) This work was supported by the Deutsche Forschungsgemeinschaft.

\section{Materials and Methods}

Toluene diisocyanate (mixture of $80: 30$ of 2,4 and 2,6 isomers) and diamino toluene (Merck, Darmstadt), human serum albumin (Sigma Chemicals, St. Louis), Phadebas RAST kit (Pharmacia, Uppsala), N-1-naphthylenediamine hydrochloride (Eastman Kodak).

Preparation of toluene diisocyanate human serum albumin conjugates

Two methods were used:

Method-1 was similar to that described by Tse \& Pesce (5). Briefly, $1 \mathrm{~g}$ human serum albumin was dissolved in $100 \mathrm{ml}$ buffer composed of sodium potassium phosphate $(0.248 \mathrm{~mol} / \mathrm{l})$, sodium chloride $(0.15 \mathrm{~mol} / \mathrm{l}), \mathrm{pH} 7.4$. To this solution $2.2 \mathrm{ml}$ of toluene diisocyanate were added dropwise over a period of 5 minutes while stirring at room temperature, incubation was continued for 15 minutes more, then an equal volume of ammonium chloride solution $(2 \mathrm{~mol} / 1)$ was added. The reaction mixture was centrifuged, filtered and exhaustively dialyzed against ammonium carbonate $(0.1 \mathrm{~mol} / \mathrm{l})$, then against water, lyophilized and kept as a powder at $-20^{\circ} \mathrm{C}$.

Method-2 was similar to that described by Scheel et al. (6) and subsequently used by other investigators (7). According to this method, $1 \mathrm{~g}$ human serum albumin was dissolved in $100 \mathrm{ml}$ of a buffer solution containing potassium chloride $(0.05 \mathrm{~mol} / \mathrm{l})$, sodium borate $(0.05 \mathrm{~mol} / \mathrm{l}), \mathrm{pH} 9.4$, and cooled to $4^{\circ} \mathrm{C}$. Dioxane $(100 \mathrm{ml})$ containing $0.15 \mathrm{ml}$ of toluene diisocyanate was then added dropwise while stirring over a period of 3 hours, followed by addition of $2 \mathrm{ml}$ of ethanolamine, centrifugation, dialysis and lyophilization. 
Coupling of conjugates and human serum albumin to activated paper discs

Known amounts of toluene diisocyanate-human serum albumin conjugates were dissolved in water, cleared by centrifugation at high speed and the clear solutions were divided into two parts. One part was kept for chemical analysis, and sodium hydrogen carbonate was added to the second part in a final concentration of $0.1 \mathrm{~mol} / 1$ and used for coupling to $\mathrm{CNBr}$-activated paper discs as described by Ceska et al. (8). Pure human serum albumin was coupled to activated paper discs in the same way. In all cases $10 \mathrm{mg}$ of conjugates or human serum albumin were dissolved in $2 \mathrm{ml}$ of coupling buffer and used for coupling to equal amounts of activated paper discs $(40 \mathrm{mg})$, under exactly the same conditions.

\section{Analyses}

Protein concentrations in solutions of human serum albumin and toluene diisocyanate-human serum álbumin conjugates were determined by the micro-biuret method (9).

For determination of the degrees of chemical substitution in the conjugates, i.e. the number of moles of isocyanate residues per mol of human serum albumin, the method of Marcali (10) adapted by Tse \& Pesce (5) was used. Briefly, known amounts of the conjugates were hydrolyzed with hydrochloric acid $(6 \mathrm{~mol} / \mathrm{l})$ for 24 hours at $100^{\circ} \mathrm{C}$. The hydrolysates were then evaporated to dryness and the residues were dissolved in $0.42 \mathrm{~mol} / 1 \mathrm{HCl}-0.385 \mathrm{~mol} / 1$ acetic acid solution, diazotized and coupled to $\mathrm{N}-1$-naphthylenediamine hydrochloride. The colour intensities of the formed azo dyes were measured at $540 \mathrm{~nm}$ and the amount of diazotizable amines were read from a standard curve constructed with diamino-toluene.

Sera for investigation were obtained from 9 workers with histories of asthmatic symptoms in connection with occupational exposure to toluene diisocyanate vapours. 4 out of these 9 patients were subjected to provocative inhalation challenge. Using toluene diisocyanate vapours at concentrations from 0.007 to $0.14 \mathrm{mg} / \mathrm{m}^{3}$, this led to significant increases in airway resistance $(>50 \%)$ in all cases (4). Intracutaneous testing with toluene diisocyanate-human serum albumin and $p$-tolyl isocyanate-human serum albumin conjugates confirmed type I sensitization in 4 out of 5 subjects. These persons showed the typical immediate wheel and flare reactions. In contrast, 15 healthy control persons gave negative results when subjected to this intracutaneous test under the same conditions.

Sera were also obtained from 9 persons not known to have been exposed to isocyanate vapours but who had total $\operatorname{lgE}$ values comparable to those of the 9 test persons.

Radio-allergo-sorbent-test (RAST) was carried out as described elsewhere (4). For RAST inhibition tests, equal volumes of one serum found to contain high titres of isocyanate-specific IgE antibodies were incubated with increasing amounts of toluene diisocyanate-human serum albumin conjugates prepared by method 1 or method 2 for 1 hour at room temperature, then at $4{ }^{\circ} \mathrm{C}$ overnight. Then to each incubation mixture one paper disc carrying toluene diisocyanate-human serum albumin conjugates prepared by method 1 was added; further incubation, washing and reacting with radiolabeled anti-human $\operatorname{IgE}$ antiserum were as usual for $\operatorname{RAST}(4,11)$.

Total IgE levels in sera were determined using the PRIST ${ }^{\circledR}$ kit from Pharmacia (12) and values were expressed in PRIST U/ml.

\section{Results}

Toluene diisocyanate-human serum albumin conjugates prepared by method 2 were found to have significantly higher degrees of substitution than those prepared by method 1 . This can be seen from the absorption spectra of the conjugates (fig. 1); conjugates containing greater amounts of toluene diisocyanate are characterized by higher UV absorption.
Chemical analysis showed that the degree of substitution of toluene diisocyanate-human serum albumin conjugates prepared by method 1 differed from one preparation to another, but were all in the range of $18-28 \mathrm{~mol}$ toluene diisocyanate per mol of proteịn ( 7 batches). The degrees of substitution of toluene diisocyanate-human serum albumin conjugates prepared by method 2 were in the range of $43-50 \mathrm{~mol}$ toluene diisocyanate per mol protein for different preparations ( 8 batches).

Three toluene diisocyanate-human serum albumin conjugates prepared by method 1 and containing 21.9 , 21.8 , and 25.7 mol toluene diisocyanate/mol human serum albumin as well as three conjugates of method 2 with degrees of substitution of 52.6, 46,1 , and $43.1 \mathrm{~mol}$ toluene diisocyanate/mol human serum albumin were used in this study. The RAST value of each serum was estimated using each of these 6 conjugates, all assays being run in duplicate. Nine test and nine contrôl sêrạ (Nos 1-9, and 10-18 in tab. 1) were assayed. The RAST value of each serum is given as the average of all values obtained with method 1 or method 2 conjugates, i.e. two RAST values are given for each serum, each of them being the average of 6 assays using 3 different method 1and 3 different method 2-conjugates. The RAST values with human serum albumin paper discs are also given; these values were comparable for different sera and different assays, being àlways $200-400$ counts/min per paper disc. The RAST values äre also given as the ratios of average counts of toluene diisocyannate-human serum albumin paper discs to those of human serum albumin paper discs.

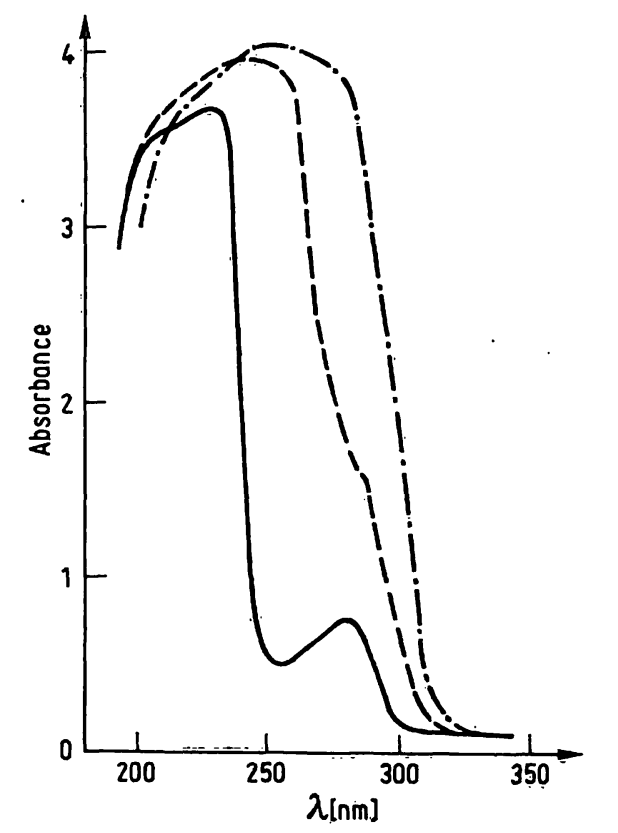

Fig. 1. Toluene diisocyanate-humàn serum albumin conjjugates prepared by method $1(---)$ and method $2(--)$ as well as human serum albumin (_) were dissolved in water to equal protein concentrations $(2 \mathrm{~g} / 1)$ and ultra violet absorption spectra were recorded. 
Tab. 1. RAST values of 9 isocyanate sensitized workers (Nos. 1-9) and of 9 control persons (Nos. 10-18) obtained with toluene disocyanate-human serum albumin conjugates prepared by method 1 (TDI-HSA-M-1) or method 2 (TDI-HSA-M-2) and human serum albumin (HSA) bound to paper discs as antigens.

Each TDI-HSA-M-1 and TDI-HSA-M-2 RAST value is the average of 6 estimations using either 3 different TDI-HSA-M-1 or 3 different TDI-HSA-M-2 preparations, respectively. In the last two columns the ratios of TDI-HSA-M-1 and TDI-HSA-M-2 RAST values to that of HSA RAST value for each serum are given.

\begin{tabular}{|c|c|c|c|c|c|c|c|c|c|c|c|}
\hline \multirow[t]{2}{*}{$\begin{array}{l}\text { Serum } \\
\text { No. }\end{array}$} & \multirow{2}{*}{$\begin{array}{l}\text { Total IgE } \\
\mathrm{U} / \mathrm{ml}\end{array}$} & \multicolumn{2}{|c|}{$\begin{array}{l}\text { Counts/min per disc } \\
\text { TDI-HSA-M-1 }\end{array}$} & \multicolumn{2}{|c|}{ TDI-HSA-M-2 } & \multirow[t]{2}{*}{ HSA } & & \multicolumn{2}{|c|}{$\frac{\text { TDI-HSA-M-1 }}{\text { HSA }}$} & \multicolumn{2}{|c|}{$\frac{\text { TDI-HSA-M-2 }}{\text { HSA }}$} \\
\hline & & Mean & SD & Mean & SD & & & Mean & SD & Mean & SD \\
\hline $\begin{array}{l}1 \\
2 \\
3 \\
4 \\
5 \\
6 \\
7 \\
8 \\
9\end{array}$ & $\begin{array}{r}2700 \\
337 \\
170 \\
900 \\
620 \\
620 \\
44 \\
340 \\
600\end{array}$ & $\begin{array}{r}4378 \\
6200 \\
12666 \\
7858 \\
15620 \\
4357 \\
6873 \\
4146 \\
2320\end{array}$ & $\begin{array}{l}425 \\
700 \\
512 \\
580 \\
840 \\
233 \\
680 \\
330 \\
200\end{array}$ & $\begin{array}{r}3078 \\
3417 \\
4048 \\
1840 \\
7733 \\
1427 \\
1000 \\
686 \\
374\end{array}$ & $\begin{array}{r}535 \\
320 \\
1100 \\
450 \\
1430 \\
176 \\
200 \\
190 \\
40\end{array}$ & $\begin{array}{l}323 \\
258 \\
390 \\
300 \\
215 \\
360 \\
205 \\
284 \\
222\end{array}$ & $\cdot$ & $\begin{array}{l}13.55 \\
24 \\
32.5 \\
26.2 \\
72.65 \\
12.1 \\
33.5 \\
14.6 \\
10.5\end{array}$ & $\begin{array}{l}1.32 \\
2.81 \\
1.30 \\
1.96 \\
4 \\
0.65 \\
3.3 \\
1.2 \\
1\end{array}$ & $\begin{array}{c}9.53 \\
13.24 \\
10.4 \\
6.14 \\
26.4 \\
3.96 \\
4.87 \\
2.4 \\
1.7\end{array}$ & $\begin{array}{l}1.66 \\
1.24 \\
2.82 \\
1.51 \\
4.7 \\
0.5 \\
1 \\
0.7 \\
0.2\end{array}$ \\
\hline $\begin{array}{l}10 \\
11 \\
12 \\
13 \\
14 \\
15 \\
16 \\
17 \\
18\end{array}$ & $\begin{array}{r}470 \\
828 \\
100 \\
1300 \\
1600 \\
619 \\
4730 \\
586 \\
156\end{array}$ & $\begin{array}{r}485 \\
394 \\
268 \\
1030 \\
538 \\
375 \\
767 \\
560 \\
275\end{array}$ & $\begin{array}{r}64 \\
28 \\
27 \\
108 \\
60 \\
23 \\
100 \\
46 \\
23\end{array}$ & $\begin{array}{r}1345 \\
960 \\
350 \\
1010 \\
1255 \\
727 \\
2246 \\
1600 \\
425\end{array}$ & $\begin{array}{r}340 \\
150 \\
50 \\
120 \\
90 \\
100 \\
200 \\
180 \\
40\end{array}$ & $\begin{array}{l}330 \\
268 \\
225 \\
262 \\
306 \\
268 \\
400 \\
350 \\
390\end{array}$ & • & $\begin{array}{l}1.47 \\
1.46 \\
1.2 \\
3.87 \\
1.78 \\
1.37 \\
1.93 \\
1.6 \\
0.68\end{array}$ & $\begin{array}{l}0.2 \\
0.1 \\
0.12 \\
0.35 \\
0.21 \\
0.08 \\
0.25 \\
0.18 \\
0.05\end{array}$ & $\begin{array}{l}4.1 \\
3.6 \\
1.56 \\
3.85 \\
4.2 \\
2.92 \\
5.44 \\
4.3 \\
1.02\end{array}$ & $\begin{array}{l}1 \\
0.6 \\
0.2 \\
0.40 \\
0.32 \\
0.16 \\
0.41 \\
0.56 \\
0.2\end{array}$ \\
\hline
\end{tabular}

The results tabulated in the table can be summarised in the following points:

1. The RAST values of almost all test sera obtained with method 1-conjugates are more than twice as high as those obtained using method' 2-conjugates. With the control sera the situation is reversed, i.e. method 2 =conjugates always gave higher counts than method 1-conjugates.

2. The higher the IgE values of the control sera the higher are their RAST values with method 2-conjugates; this correlation is much less pronounced with method 1-conjugates.

3. Only one test serum (No. 1) gave similar RAST values with conjugates of both methods; this, however, may be due to the high level of total IgE in this serum leading to additional non-specific binding of $\operatorname{IgE}$ to the method 2 conjugates.

4. Using method 2-conjugates, 4 of the nine test sera (Nos. 6, 7, 8 and 9) gave RAST values comparable to those of the control sera; using method 1-conjugates, however, RAST values for these same sera were obtained which are significantly higher than those of the controls.

Because of the high degree of substitution in method 2conjugates, only a limited number of free amino groups could have been available for binding to the activated paper discs, which may explain the lower RAST results obtained with these conjugates. In order to test this hypothesis, RAST inhibition experiments were carried out, in which equal amounts of one test serum were incubated with increasing amounts of either method 1or method 2-conjugates, then specific IgE antibodies were measured by RAST, using paper discs carrying method 1-conjugates.

The results of these inhibition RASTs are represented in figure 2 . It can be seen that more than $75 \%$ RAST inhibition could be produced by preincubation of the serum

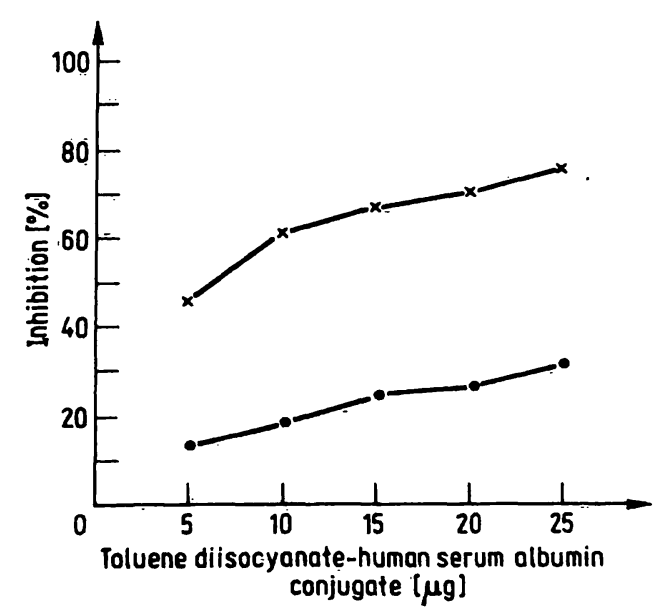

Fig. 2. Equal aliquots of one serum containing isocyanate-specific IgE were incubated with different amounts of either toluene diisocyanate-human serum albumin conjugates prepared by method $1(x-x)$ or method $2(\bullet-\bullet)$ for 1 hour at room temperature, then overnight at $4^{\circ} \mathrm{C}$. Then the isocyanate-specific IgE antibodies in these serum aliquots were estimated by RAST using toluene diisocyanate-human serum albumin conjugate prepared by method 1 coupled to paper discs. 
with $25 \mu \mathrm{g}$ of method 1-conjugates, whereas the same amount of method 2-conjugates produced only about $30 \%$ inhibition. This indicates that the lower RAST results obtained by method 2-conjugates cannot be due to a weaker binding to the paper discs, but rather to its lower affinity to the IgE antibodies. These RAST inhibition results were reproducible, using different test sera and different combinations of the toluene diisocyanatehuman serum albumin conjugates in the solid and liquid phases of the RAST.

\section{Discussion}

The results reported here from RAST and RAST inhibition experiments show that human serum albumin-isocyanate conjugates with lower degrees of substitution are more capable of binding specific IgE than conjugates having almost twice as much isocyanate moles per mol carrier. These differences in IgE binding are not due to differences in amounts of conjugates bound to the activated paper discs, but rather due to the chemical structures and degrees of substitution. It seems that the carrier plays a role in the binding of IgE to the conjugate. Certain "parts" of the carrier (human serum albumin) should be still available for recognition by the IgE, these parts are probably masked in conjugates containing greater amounts of the hapten (toluene diisocyanate).

That the carrier plays an important role in determing the specificity of human anti-hapten immunoglobulin $\mathrm{E}$ antibodies was also evident from our latest experiments using conjugates containing different carriers; for example: toluene diisocyanate-ovalbumin conjugates prepared

\section{References}

1. Avery, S. B., Stetson, D. M., Pan, P. M. \& Mathews, K. P. (1969) Clin. Exp. Immunol. 4, 585-596.

2. Karol, M. H. \& Alarie, Y. (1980) Clin. Allergy 10, 101-109.

3. Butcher, B. T., O'Neil, C. E., Reed, M. A. \& Salvaggio, J. E. (1980) J. Allergy Clin. Immunol. 66, 213-216.

4. Baur, X. \& Fruhmann, G. (1981) Chest 80, 73 S - 76 S.

5. Tse, C. S. T. \& Pesce, A. J. (1979) Toxicol. Appl. Pharmacol. 51, 39-46.

6. Scheel, L. D., Killens, R. \& Josephson, A. (1964) Am. Ind. Assoc. J. 25, 179-184

7. Butcher, B. T., Salvaggio, J. E., Weill, H. \& Ziskind, M. M. (1976) J. Allergy Clin. Immunol. 58, 89-100. by method 1 gave negative RAST results with almost all test sera assayed.

According to these results the human hapten-specific IgE seems to behave in a different way from that of experimental rabbit hapten-specific IgG. Scheel et al. (6) have used ovalbumin-isocyanate conjugates of different degrees of substitution for immunization of rabbits. The degrees of substitution were not exactly given. The induced hapten-specific IgG were found to have higher affinities to those conjugates with higher degrees of substitution. Similar results were obtained by Celis et al. (13) who studied dinitrophenyl-human serum albumin conjugates.

It is obvious from our results that the usefulness of RAST for detecting isocyanate specific IgE antibodies in sera of isocyanate-sensitive persons depends to a great extent on the degrees of chemical substitution in the synthetic antigens. Conjugates with high degrees of substitution are likely to give low or even negative RAST values with many sera of persons known to be sensitized towards isocyanates. These same conjugates, however, give high RAST values with sera from control persons who are neither clinically or anamnestically sensitive to isocyanate vapours. Moreover the high RAST values of control sera tested with method 2-conjugates seem to depend on the contents of total IgE in these sera (compare control sera Nos. 10, 14, 16 and 17).

Further investigations are necessary to determine whether other synthetic antigens containing different carriers and having different degreees of substitutions may be more optimal than our method 1-conjugates for assessment of the immunological sensitization towards isocyanates.

8. Ceska, M., Eriksson, R. \& Varga, J. M. (1972) J. Allergy Clin. Immunol. 49, 1-9.

9. Itzhaki, R. F. \& Gill, D. M. (1964) Anal. Biochem. 9; 401410.

10. Marcali, K. (1957) Anal. Chem. 29, 552-558.

11. Phadebas RAST, Directions for use, published by "Pharmacia Diagnostics AB, Upppsala, Sweden".

12. Phadebas IgE PRIST ${ }^{\circledR}$ Radioimmunoassay, "Phairmacia Diagnostics AB, Uppsala, Sweden".

13. Celis, E., Ridaura, R. \& Larralde, C. (1977) Immúno: chemistry $14,553-559$.

\author{
M. A. Dewair and X. Baur \\ Pulmonary Section \\ Medical Clinic I \\ Klinikum Großhạdern \\ University of Munich \\ Marchioninistr. 15 \\ Postfach 701260 \\ D-8000 Munich 70
}




\section{Walter de Gruyter \\ Berlin-New York}

\section{H. Kleinkauf H. v. Döhren (Editors)}

\section{Peptide Antibiotics Biosynthesis and Functions Enzymatic Formation of Bioactive Peptides and Related Compounds}

$1982.17 \mathrm{~cm} \times 24 \mathrm{~cm}$. XII, 479 pages. Numerous illustrations. Hardcover. DM 190,-; approx. US \$95.00 ISBN 3110084848

The book represents the current state of work in biosynthesis and functions of bioactive peptides, especially peptide antibiotics. In $\mathbf{4 0}$ contributions all aspects of the enzymatic formation of peptides are presented, including pathways, fermentation and production of peptides and synthetases, multienzyme systems and peptide bond forming reactions, modification and possible functions of peptide antibiotics within their producer organisms. The compounds discussed are gramicidin S, gramicidin, tyrocidine, bacitracin, polymyxins, penicillins and cephalosporins, actinomycin, mycobacillin, ergot peptides, edeine, leupeptin, carnosin, folyl-poly- $\gamma$-glutamates, amatoxins, and the poly- $\gamma-D-$ glutamyl capsule.

\section{Neuroreceptors}

\section{Proceedings of the Symposium Berlin (West), September 28-29, 1981}

$1982.17 \mathrm{~cm} \times 24 \mathrm{~cm}$. XIV, 367 pages. Numerous illustrations. Hardcover. DM 150,-; approx. US \$75.00 ISBN $311008855 X$

This volume contains reviews and original data on some of the neural receptors, which are at present the focus of interest. They were presented at a meeting held in Berlin on September 28 and 29, 1981. More than half of the volume deals with the nicotinic acetylcholine receptor, not merely because we consider this receptor the most interesting or the most important molecule of its kind, but also because we feel that its biochemical investigation is, for technical reasons, at present fairly advanced.

Whereas some of the other receptors presented here have not yet gone farther than the stage of hypothesis, others are already visible at least on autoradiograms, after radioactive labelling. The basic questions and the techniques for answering these appear to be very similar so that any exchance of ideas and experiences appears to be useful. 


\section{Walter de Gruyter Berlin-New York}

D. Brandenburg A. Wollmer

(Editors)

\author{
K. Keck \\ P. Erb \\ (Editors)
}

Insulin

Chemistry, Structure and Function of Insulin and Related Hormones

Proceedings of the Second International Insulin Symposium, Aachen, Germany, September 4-7, 1979

$1980.17 \mathrm{~cm} \times 24 \mathrm{~cm} .752$ pages. Numerous figures.

Hardcover. DM 170,-; approx. US $\$ 85.00$

ISBN 3110081563

These proceedings of the Insulin Symposium present the current state of knowledge and research in the field of Insulin. The problems are presented and discussed from various standpoints (chemistry, biochemistry, bioloḡy, crystallography, immunology and medicine).

Contents: Introduction

Sections I-XI

Structure of Insulin - Peptide Synthesis - Semisynthesis and Chemical Modification - Radioactive Labelling and Separation Techniques - Receptors and Hormone-Receptor Interaction Photo-Induced Hormone-Receptor Coupling - Structure, Binding, Activity - Degradation - Immunology - Biosynthesis, Storage, Evolution · Insulin-Related Hormones.

Abbreviations - Subject Index · Author Index.,..

\section{Basic and Clinical Aspects of Immunity to Insulin}

\section{Proceedings. International Workshop, September 28-October 1, 1980, Konstanz, Germany}

1981. $17 \mathrm{~cm} \times 24 \mathrm{~cm}$. XIV, 442 pages. Numerous illustrations. Hardcover. DM 140,-; approx. US \$70:00

ISBN 3110084406

In order to integrate the large quantities of information available regärding the chemistry and immunology of insulin as well as the clinical aspects of diabetes and its control, it is necessary to establish interdisciplinary lines of communication between specialists in these various fields. It was the intention of a Symposium held in Konstanz, FRG, from September 28 to October 1, 1980, to bring together clinicians, immunologists and chemists active in insulin research, to provide an open forum to exchange ideas and experience, to establish contacts and to intensify cooperation between these groups. 